\title{
A Study to Assess Knowledge, Attitude and Practices Regarding Antibiotic Administration and Its Resistance among the Nursing Professionals Working in Various Institute of Chhattisgarh State
}

\author{
Rajendra Kumar Sahu', Yogita Sahu ${ }^{2}$ \\ ${ }^{1}$ Ph.D. Nursing Scholar, Mangalayatan University Aligarh, Uttar Pradesh \\ ${ }^{2}$ M.Sc. Nursing 1st Year, The Academy of Nursing Science and Hospital, Gwalior, Madhya Pradesh \\ Corresponding Author: Rajendra Kumar Sahu
}

\begin{abstract}
Introduction: Antibiotic resistance is global problem. According to World Health Organization data more than 23000 people die or become critically ill due to resistance of antibiotic therefore the unavoidable threat to human life is rising day by day. India has the highest infectious disease burden in the world and consequently antibiotics play a critical role in limiting morbidity and mortality.

Objectives: To assess knowledge attitude and practices regarding antibiotic administration and its resistance, to assess the association between knowledge, attitude and practice.

Research Methodology: Evaluative research approach and descriptive design is used in this study. The major variables in the study were knowledge, attitude and practice of nursing professionals. Self-structured knowledge questionnaire is used for collection of data.100 staff nurses were selected from population based on inclusion criteria. A non-probability convenient sampling technique was used to select samples.
\end{abstract}

Result: Total 100 nursing professional from various District of Chhattisgarh state participated in study, in which knowledge score found 27(27\%) having Adequate knowledge, $50(50 \%)$ having Moderately adequate knowledge and 23(23\%) having Inadequate knowledge, level of attitude found $38(38 \%)$ having Favourable attitude, 61(61\%) having Moderate attitude, $1(1 \%)$ Unfavourable attitude and level of practice found $22(22 \%)$ having Good practice, $46(46 \%)$ having Moderate practice score and 32 (32\%) having Poor practice score. Correlation found between Knowledge \& Practice. Correlation is significant at the 0.01 level.

Keywords: Antibiotic resistance, antibiotic administration, nursing professionals

\section{INTRODUCTION}

Antibiotic resistance is global problem. According to World Health Organization data more than 23000 people die or become critically ill due to resistance of antibiotic therefore the unavoidable threat to human life is rising day by day. Antimicrobial resistance is one of the major health problems in developing countries like India where relatively easy availability and higher consumption leads to disproportionately higher level of antibiotic resistance (1). India has the highest infectious disease burden in the world and consequently antibiotics play a critical role in limiting morbidity and mortality. Management of common and lethal bacterial infections has been critically compromised by the appearance and rapid spread of antibiotic resistant bacteria. A recent report showed that inappropriate and irrational use of antimicrobial agents against these diseases led to the increase in development of antimicrobial resistance (2). Only the extent and percentage of antibiotic resistance varies from country to country 
Rajendra Kumar Sahu et.al. A study to assess knowledge, attitude and practices regarding antibiotic administration and its resistance among the nursing professionals working in various institute of Chhattisgarh State

but the underlying problem of resistance and misuse remains the same globally. Inappropriate and irrational use of medicines provides favourable conditions for resistant microorganisms to emerge and spread. Irrational use of antibiotics also involves self-medication, i.e. antibiotics purchased from pharmacies without prescription, or leftover antibiotics from previous course of treatment (3). It is estimated that more than $50 \%$ of antibiotics worldwide are purchased privately without a prescription from pharmacies (4). Over the counter purchase of antibiotics is a very common picture seen across our country where antibiotics are dispensed as a single dose therapy even for a milder illness like flu. Nurses place a crucial role in combating antimicrobial resistance; they play key roles in antibiotic management and infection control, two main preventive measure of antibiotic resistance (5). Nurses work as health educator for to patients and community, they are main sources of education for them. Assessment of knowledge, attitudes and practices regarding antibiotic administration and its resistance among the Nursing professional will provide the information regarding gaps exists between knowledge attitude and practices, need of intervention which will enable strengthening of knowledge and skill of nursing professionals.

\section{Objectives}

* To assess knowledge attitude and practices regarding antibiotic administration and its resistance.

* To assess the association between knowledge, attitude and practice.

\section{RESEARCH METHODOLOGY}

Evaluative research approach and descriptive design is used in this study

Sample Size: 100 staff nurses were selected from population based on inclusion criteria.
Sampling Technique: A non-probability convenient sampling technique was used to select samples.

\section{Inclusion Criteria}

1. Nursing professionals working in Chhattisgarh.

2. Nursing professionals willing to participate in the study.

\section{Exclusion Criteria}

1. Nursing professional who not did certified basic nursing training course.

2. Nursing professionals who are not willing to participate.

\section{Tools}

Self-structured questionnaire is prepared.

knowledge

Component of tools - It consists 2 section-

A. Socio demographic data-Includes Sociodemographic information of sample population.

B. Self-structured knowledge questionnaire.-Divided in 3 Section

1. Knowledge regarding antibiotic administration and resistanceincludes 10 questions; each item consisted of one right answer or key and three distractors.

2. Attitude scale- contains 10 questions, Five point Likert scale (agree, strongly agree, uncertain, disagree, strongly disagree) is used.

3. Practices questions- Contains 10 questions related practices.

\section{RESULT}

Total 100 nursing professional from various District of Chhattisgarh state participated in study, in which most of participant $77 \%$ belongs to $20-30$ year of age group and $71 \%$ participants was females. When the knowledge, attitude and practice level of participants is assessed, knowledge score found 27(27\%) having Adequate knowledge, 50(50\%) having moderately adequate knowledge and $23(23 \%)$ having Inadequate knowledge, 
Rajendra Kumar Sahu et.al. A study to assess knowledge, attitude and practices regarding antibiotic administration and its resistance among the nursing professionals working in various institute of Chhattisgarh State

level of attitude found $38(38 \%)$ having Favourable attitude, 61(61\%) having Moderate attitude, 1(1\%) Unfavourable attitude and level of practice found 22(22\%) having Good practice, 46(46\%) having
Moderate practice score and 32(32\%) having Poor practice score. Correlation found between Knowledge \& Practice. Correlation is significant at the 0.01 level.

Table 01: Socio-demographic Frequency Distribution of Sample Population

\begin{tabular}{|c|c|c|}
\hline \multicolumn{3}{|c|}{ Sociodemographic Variable } \\
\hline \multicolumn{3}{|r|}{$\mathrm{N}=100$} \\
\hline & Frequency & Percentage \\
\hline \multicolumn{3}{|l|}{ Age Group } \\
\hline $20-30$ & 77 & $77 \%$ \\
\hline $30-40$ & 22 & $22 \%$ \\
\hline $40-50$ & 1 & $1 \%$ \\
\hline $50-60$ & 0 & 0 \\
\hline \multicolumn{3}{|l|}{ Gender } \\
\hline Male & 29 & $29 \%$ \\
\hline Female & 71 & $71 \%$ \\
\hline \multicolumn{3}{|l|}{ Professional Experience } \\
\hline Below 5 Year & 73 & $73 \%$ \\
\hline 5-10 Year & 26 & $26 \%$ \\
\hline 10-15 Year & 1 & $1 \%$ \\
\hline 15-20 Year & 0 & $0 \%$ \\
\hline \multicolumn{3}{|l|}{ Qualification } \\
\hline ANM & 6 & $6 \%$ \\
\hline GNM & 17 & $17 \%$ \\
\hline B.sc Nursing & 67 & $67 \%$ \\
\hline M.Sc. Nursing & 10 & $10 \%$ \\
\hline Ph.D. Nursing & 0 & 0 \\
\hline \multicolumn{3}{|l|}{ Designation } \\
\hline Nurse Tutor & 28 & $28 \%$ \\
\hline Nursing Officer Grade - II & 42 & $42 \%$ \\
\hline Community Health officer & 18 & $18 \%$ \\
\hline Senior Nursing Officer & 6 & $6 \%$ \\
\hline Axillary Nurse Midwife & 6 & $6 \%$ \\
\hline \multicolumn{3}{|l|}{ Type of Job } \\
\hline Private & 53 & $53 \%$ \\
\hline Contract/Samvida & 25 & $25 \%$ \\
\hline Regular & 22 & $22 \%$ \\
\hline Daily Wages & 0 & $0 \%$ \\
\hline \multicolumn{3}{|l|}{ Work Setting } \\
\hline Primary Health Centre & 15 & $15 \%$ \\
\hline Private Hospital & 42 & $42 \%$ \\
\hline Community Health Centre & 13 & $13 \%$ \\
\hline Nursing College/School & 15 & $15 \%$ \\
\hline District Hospital & 15 & $15 \%$ \\
\hline \multicolumn{3}{|c|}{ Usual Source of Information on Antibiotics or Other Drugs } \\
\hline Literature Provided by Medical Representatives & 42 & $42 \%$ \\
\hline Information Obtained from Other & 17 & $17 \%$ \\
\hline Internet or Other Online Platform & 41 & $41 \%$ \\
\hline
\end{tabular}

Table02: Knowledge Score

\begin{tabular}{|c|l|c|c|}
\hline $\begin{array}{c}\text { S. } \\
\text { No. }\end{array}$ & Level of Knowledge & Frequency & $\begin{array}{c}\text { Percentage } \\
(\mathbf{\%})\end{array}$ \\
\hline 1 & Adequate Knowledge & 27 & $27 \%$ \\
\hline 2 & $\begin{array}{l}\text { Moderately Adequate } \\
\text { Knowledge }\end{array}$ & 50 & $50 \%$ \\
\hline 3 & Inadequate Knowledge & 23 & $23 \%$ \\
\hline
\end{tabular}

Table 03: Practice Score

\begin{tabular}{|c|l|c|c|}
\hline $\begin{array}{c}\text { S. } \\
\text { No }\end{array}$ & Level of Practice & Frequency & $\begin{array}{c}\text { Percentage } \\
(\boldsymbol{\%})\end{array}$ \\
\hline 1 & Good Practice & 22 & $22 \%$ \\
\hline 2 & Moderate Practice & 46 & $46 \%$ \\
\hline 3 & Poor Practice & 32 & $32 \%$ \\
\hline
\end{tabular}

Table 04: Attitude Score

\begin{tabular}{|c|l|c|c|}
\hline $\begin{array}{c}\text { S. } \\
\text { No. }\end{array}$ & Level of Attitude & Frequency & $\begin{array}{c}\text { Percentage } \\
(\boldsymbol{\%})\end{array}$ \\
\hline 1 & Favourable Attitude & 38 & $38 \%$ \\
\hline 2 & Moderate Attitude & 61 & $61 \%$ \\
\hline 3 & Un favourable Attitude & 1 & $1 \%$ \\
\hline
\end{tabular}

Table 05: Correlation between Variables

\begin{tabular}{|c|l|c|}
\hline \multicolumn{2}{|c|}{ Variable } & Score \\
\hline Knowledge \& Attitude & Pearson Correlation & -0.004 \\
\cline { 2 - 3 } & Sig. (2-tailed) & 0.969 \\
\hline Attitude \& Practice & Pearson Correlation & 0.032 \\
\cline { 2 - 3 } & Sig. (2-tailed) & 0.754 \\
\hline Knowledge \& Practice & Pearson Correlation & $.456^{* *}$ \\
\cline { 2 - 3 } & Sig. (2-tailed) & $<.001$ \\
\hline
\end{tabular}

**. Correlation is significant at the 0.01 level 
Rajendra Kumar Sahu et.al. A study to assess knowledge, attitude and practices regarding antibiotic administration and its resistance among the nursing professionals working in various institute of Chhattisgarh State

Table 06: Question Wise Knowledge Score

\begin{tabular}{|c|c|c|c|}
\hline S.N. & & Correct & Incorrect \\
\hline 1. & $\begin{array}{l}\text { A condition when germs like bacteria and fungi develop the ability to defeat the drugs designed to kill / } \\
\text { inhibit them is called. }\end{array}$ & 69 & 31 \\
\hline 2. & Do you think you have enough sources of information about antibiotics when you need it? & 56 & 44 \\
\hline 3. & Do you know of any guidelines related to antibiotic use? & 56 & 44 \\
\hline 4. & Ceftriaxone is which class of cephalosporin? & 65 & 35 \\
\hline 5. & $\begin{array}{l}\text { Do you know which investigation report is importance to see before administering antibiotic to older } \\
\text { patient or patient having kidney problem? }\end{array}$ & 75 & 25 \\
\hline 6. & $\begin{array}{l}\text { A hospitalized patient having Catheter associated infection, which one treatment option will you follow in } \\
\text { management of Catheter associated infection? }\end{array}$ & 73 & 27 \\
\hline 7. & A 30 year female patient having acute uncomplicated cystitis, which drug will you recommend? & 51 & 49 \\
\hline 8. & $\begin{array}{l}\text { A } 40 \text { year-old woman comes to you complaining of } 4 \text { days of watery loose stools } \\
\text { with 1-2 episodes of vomiting. No history of fever. Which antibiotic will you recommend? }\end{array}$ & 67 & 33 \\
\hline 9. & Which one of the following antibiotics is contraindicated in pregnancy? & 40 & 60 \\
\hline 10. & Which one of anti-malarial drugs is used in treatment of covid-19? & 67 & 33 \\
\hline
\end{tabular}

Table 07: Attitude Score of Participants

\begin{tabular}{|c|c|c|c|c|c|c|}
\hline S.N. & Question & $\begin{array}{l}\text { Strongly } \\
\text { Agree }\end{array}$ & Agree & Neutral & Disagree & $\begin{array}{l}\text { Strongly } \\
\text { Disagree }\end{array}$ \\
\hline 1. & Antibiotics are useful for bacterial infections (i.e. typhoid) & $53.0 \%$ & $33.0 \%$ & $9.0 \%$ & $2.0 \%$ & $2.0 \%$ \\
\hline 2. & Antibiotics are useful for viral infections (i.e. flu) & $17.0 \%$ & $37.0 \%$ & $14.0 \%$ & $20.0 \%$ & $11.0 \%$ \\
\hline 3. & $\begin{array}{l}\text { Antibiotics are indicated to reduce the symptoms of pain and } \\
\text { inflammation in body }\end{array}$ & $14.0 \%$ & $35.0 \%$ & $17.0 \%$ & $24.0 \%$ & $10.0 \%$ \\
\hline 4. & $\begin{array}{l}\text { Antibiotic resistance is a phenomenon for which a bacterium loses } \\
\text { its sensitivity to an antibiotic }\end{array}$ & $24.0 \%$ & $51.0 \%$ & $8.0 \%$ & $13.0 \%$ & $3.0 \%$ \\
\hline 5. & $\begin{array}{l}\text { Antibiotics are overused without any prescription in the } \\
\text { community in India }\end{array}$ & $23.0 \%$ & $47.0 \%$ & $11.0 \%$ & $15.0 \%$ & $3.0 \%$ \\
\hline 6. & $\begin{array}{l}\text { Patient's demands for antibiotics contribute to overuse of } \\
\text { antibiotics. }\end{array}$ & $13.0 \%$ & $43.0 \%$ & $19.0 \%$ & $19.0 \%$ & $6.0 \%$ \\
\hline 7. & $\begin{array}{l}\text { General knowledge on antibiotic resistance should be considered } \\
\text { when antibiotics are prescribed to an individual patient }\end{array}$ & $19.0 \%$ & $53.0 \%$ & $13.0 \%$ & $14.0 \%$ & $1.0 \%$ \\
\hline 8. & $\begin{array}{l}\text { I believe that prescribing antibiotics is harmful to patients if not } \\
\text { indicated. }\end{array}$ & $29.0 \%$ & $47.0 \%$ & $11.0 \%$ & $9.0 \%$ & $4.0 \%$ \\
\hline 9. & $\begin{array}{l}\text { I would like access to educational programs on antibiotic } \\
\text { prescription }\end{array}$ & $33.0 \%$ & $52.0 \%$ & $10.0 \%$ & $5.0 \%$ & 0 \\
\hline 10. & I can do something to combat antibiotic resistance in my practice. & $27.0 \%$ & $53.0 \%$ & $12.0 \%$ & $6.0 \%$ & $2.0 \%$ \\
\hline 11. & Antibiotic resistance is a problem worldwide & $12.0 \%$ & $64.0 \%$ & $13.0 \%$ & $9.0 \%$ & $2.0 \%$ \\
\hline 12. & $\begin{array}{l}\text { A patient has been prescribed a full course of antibiotics. She } \\
\text { stopped it after } 3-4 \text { doses as she had started feeling better. Do you } \\
\text { find this appropriate? }\end{array}$ & $9.0 \%$ & $42.0 \%$ & $19.0 \%$ & $14.0 \%$ & $15.0 \%$ \\
\hline
\end{tabular}

Table: 08 Items Wise Practice Score

\begin{tabular}{|c|c|c|c|c|c|}
\hline S.N. & Question & Never & Sometimes & $\begin{array}{l}\text { Most of the } \\
\text { time }\end{array}$ & Always \\
\hline 1. & Antibiotic resistance I observes in my routine practice & $10.0 \%$ & $62.0 \%$ & $13.0 \%$ & $15.0 \%$ \\
\hline 2. & $\begin{array}{l}\text { How frequently do you review prescribe antibiotics before } \\
\text { giving patient? }\end{array}$ & $7.0 \%$ & $40.0 \%$ & $19.0 \%$ & $34.0 \%$ \\
\hline 3. & $\begin{array}{l}\text { How frequently do you explain the proper usage of antibiotics } \\
\text { to patients? }\end{array}$ & $6.0 \%$ & $33.0 \%$ & $24.0 \%$ & $37.0 \%$ \\
\hline 4. & Do you check creatinine level before administering antibiotic? & $14.0 \%$ & $42.0 \%$ & $18.0 \%$ & $25.0 \%$ \\
\hline 5. & Do you check skin sensitivity before starting first IV dose? & $7.0 \%$ & $32.0 \%$ & $23.0 \%$ & $38.0 \%$ \\
\hline 6. & $\begin{array}{l}\text { Do you follow Five Rights of Medication Administration for } \\
\text { the proper administration of antibiotics to patients? }\end{array}$ & $1.0 \%$ & $18.0 \%$ & $12.0 \%$ & $69.0 \%$ \\
\hline 7. & $\begin{array}{l}\text { How frequently do you read information literature available } \\
\text { with antibiotic? }\end{array}$ & $9.0 \%$ & $42.0 \%$ & $21.0 \%$ & $28.0 \%$ \\
\hline 8. & $\begin{array}{l}\text { How frequently do you follow drug dilution and administration } \\
\text { guideline for administering intravenous antibiotic drug? }\end{array}$ & $7.0 \%$ & $35.0 \%$ & $17.0 \%$ & $41.0 \%$ \\
\hline 9. & $\begin{array}{l}\text { How frequently do you advice or provide an antibiotic for a } \\
\text { cold or sore throat? }\end{array}$ & $\begin{array}{c}\text { None of my } \\
\text { patients } \\
13.0 \%\end{array}$ & $\begin{array}{c}\text { Some of my } \\
\text { patients } \\
44.0 \% \\
\end{array}$ & $\begin{array}{c}\text { Most of my } \\
\text { patients } \\
21.0 \% \\
\end{array}$ & $\begin{array}{c}\text { All of my } \\
\text { patients } \\
22.0 \% \\
\end{array}$ \\
\hline
\end{tabular}

\section{DISCUSSION}

In our study most of them were aware of worldwide and national level problem of antimicrobial resistance, but at their own hospital, the antibiotic resistance was not considered to be a serious issue. A similar response was noted in previous studies where most of the participants did not give importance with the prevalence of the antibiotic resistance at their own institution. The attitude of the nursing professionals with regards to antibiotic 
Rajendra Kumar Sahu et.al. A study to assess knowledge, attitude and practices regarding antibiotic administration and its resistance among the nursing professionals working in various institute of Chhattisgarh State

administration and resistance was found to be not very serious and was very much casual in their approach towards on usage of it. Where $38 \%$ of nursing professionals found with Favourable attitude, $61 \%$ found with Moderate attitude and only $1 \%$ of nursing professional found with Unfavourable attitude While assessing the practice level, result revealed that $22 \%$ of nursing professional having Good practice, $46 \%$ having Moderate practice score and $32 \%$ having Poor practice score. Correlation found between Knowledge \& Practice. Correlation is significant at the 0.01 level. To combat antimicrobial resistance problems there is necessary to organise educational programme to enhance the knowledge level of nursing professionals.

\section{CONCLUSION}

The present study on assessment of knowledge, attitude and practices regarding antimicrobial resistance gives useful information about the knowledge, attitudes and the practices of nursing professionals working in Chhattisgarh state, which may be utilized to plan suitable educational interventions/small group exercises that aim at improving the efficient antimicrobial administration, proper use (adherence) by the patients in order to minimize the development of drug resistance.

Acknowledgement: None

Funding: No funding sources

Conflict of Interest: None Declared

Ethical Approval: Approved

\section{REFERENCES}

1. S. Ganesh Kumar, C. Adithan, B. N. Harish, S. Sujatha, Gautam Roy, and A. Malini, Antimicrobial resistance in India: A review. Journal of Natural Science Biology and Medicine. July 4, 2013, pp. 286-291.

2. Singh, N.P. Losing the battle against bacteria. Maulana Azad Medical College. Livemint News, 2013.

3. Grigoryan L, Haaiher-Ruskamp FM, Burgerhof JG, et al. Self-medication with antimicrobial drugs in Europe. 2006. Pubmed. pp. 452-9.

4. Ganchimeg Togoobaatar, Nayu Ikeda, Moazzam Ali, Munkhbayarlakh Sonomjamts, Sarangerel Dashdemberel, Rintaro Mori \& Kenji Shibuya. Bulletin of the World Health Organization. World Health Organization. [Online] September 3, 2010. [Cited: January 30, 2020.] https://www.who.int/bulletin/volumes/88/12 /10-079004/en/.

5. Mathanki Jayaweerasingam, Sacheera Kapruk Angulmaduwa and Veranja Liyanapathirana. Knowledge, beliefs and practices on antibiotic use and resistance among a group of trainee nurses in Sri Lanka. British Society for Microbial Chemotherapy. BSAC Spring Conference 2019 Global views, local problems: Innovative solutions to AMR and infection challenges. Birmingham, United Kingdom. $21^{\text {st }}$ and $22^{\text {nd }}$ March 2019.

How to cite this article: Sahu RK, Sahu Y. A study to assess knowledge, attitude and practices regarding antibiotic administration and its resistance among the nursing professionals working in various institute of Chhattisgarh State. International Journal of Science \& Healthcare Research. 2021; 6(2): 17-21. DOI: https://doi.org/10.52403/ijshr.20210404 